$A D D I N$, Volume 11, Number 1, February 2017

\title{
MULTICULTURALISM IN ISLAMIC CIVILIZATION DURING THE CLASSIC PERIOD
}

\section{Dudung Abdurahman}

UIN Sunan Kalijaga Yogyakarta, Indonesia

durahman.uin@gmail.com

\section{Abstract}

The main objectives of this study are to map and analyze the multiculturalism pattern in Muslim civilization history during the period. Analyses are developed with historical and socio-cultural perspectives. Several patterns of multiculturalism in Islamic civilization are found: Firstly, during the Prophet and al-Khulafa ar-Rasyidun era, Islam-as a doctrine and religion system-had accomodative patterns to the cultural form in al-'așabiyyah al-qabaliyyah tradition and began to perform as Arabic culture-based civilization. Secondly, during the Daulah Umayyah era, disregarding that the civilization was developed using Arabic politics, the policies regarding Islamic expansion encouraged acculturation of Arabic-Muslim and non-Arabic or nonMuslim communities, leading to the multiculturalism in Islam at that time. Finally, during the Daulah Abbasiyah era, multiculturalism became more obvious as a pattern of Islamic civilization, indicated by the roles of non-Arabic cultures in Islamic civilization development.

Keywords: Islam, Multi-Cultural Community, Muslim Civilization. 


\section{Abstrak}

Tujuan utama dari penelitian ini adalah untuk memetakan dan menganalisis pola multikulturalisme dalam sejarah peradaban Islam selama periode tersebut. Analisis yang dikembangkan menggunakan perspektif sejarah dan sosial budaya. Beberapa pola multikulturalisme dalam peradaban Islam yang ditemukan antara lain: Pertama, pada era Nabi dan al-Khulafa ar-Rasyidun, Islam-sebagai doktrin dan agama sistem-memiliki pola akomodatif ke bentuk budaya di tradisi al-'așabiyyah al-qabaliyyah dan mulai melakukan sebagai peradaban Arab berbasis budaya. Kedua, selama era Daulab Umayyah, mengabaikan bahwa peradaban ini dikembangkan menggunakan politik Arab, kebijakan mengenai ekspansi Islam mendorong akulturasi masyarakat Arab-Muslim dan non-Arab atau non-Muslim, yang mengarah ke multikulturalisme dalam Islam pada waktu itu. Akbirnya, selama era Daulah Abbasiyah, multikulturalisme menjadi lebih jelas sebagai pola peradaban Islam, ditunjukkan dengan peran budaya non-Arab dalam pembangunan peradaban Islam.

Kata Kunci: Islam, Masyarakat Mulitikultural, Peradaban Islam.

\section{A. Introduction}

Multicultularism, which generally means "views or concept about culture and behavior variation caused by difference in race, religion, and social structure", now has become an interesting issue and subject of study in understanding various social orders. It is even more appealing when we study the relationship between multiculturalism and the development of Islam. Islam has developed into diverse culture of its followers, which often becomes the reason for plenty of social and political issues among them, including in their relationship with the broader socioculture orders. Hence, study about connection between Islam and multiculturalism is expected to contribute to public understanding that Islam-as a doctrine system 
originated from God's revelation-always grows and develops correspondingly with the people's diversity context as shown in the history of Islamic civilization. Based on the historical point of view, the development of Islam and multiculturalism began in the classic period, which is the era of Prophet Muhammad saw. to the "golden era" of daulah Abbasiyah. This study is conducted on symptoms during the period that is expected to be the first phenomenons and a more fundamental historical perspective to understand Islam and multiculturalism.

Generally said, history of Islam during the classic period is the period where civilization grew and developed in Muslim community system. In this context, civilization concept can be identified from communities or ummah's advancement rate, which means the development of Islam followers in social order with all regulation and structure in it. The community shows identity in the name of similar belief, view, and society's behavior based on the teachings of Islam. Civilization in Muslim community is also defined as comprehensions, interests, and political purposes used together by Islam followers in particular territory and era. ${ }^{1}$

The growth of multicultural community during the Prophet's regime can be described as follow: not only dealing with the cultural variety among Arabic people, but also the delivery of Islam by the Prophet was done accommodatively to the people's cultural system. Muslim community in the era of Prophet Muhammad saw. was originated from a small group of the very first Islam followers, which is the Prophet's family and some people from various Arabic ethnic backgrounds (qabilab). The development of Islam in Mecca took place for about 13 years, and it was acculturative with the followers, resulting in the qabilah culture variety-

\footnotetext{
${ }^{1}$ Read Kuntowijoyo, Identitas Politik Umat Islam (Bandung: Mizan, 1997), p. 27.
} 
based Muslim community at that time. Accordingly, Prophet's propaganda in Medina for 10 years gave birth to a Muslim civilization on culture diversity, which resulted in the development of Islamic teachings that accommodate civilization with different groups, ethnics, and religions.

This also happened to the development of Muslim community after Prophet Muhammad saw's era, which encountered an expansion hugely effecting the culture diversity and improvement of Islamic civilization. Starting with changes in socio-political system during the Khulafa al-Rasyidin period, when Muslim community expanded and developed in ethnic regions in Arab and its surroundings. The four caliphs' effort in this period indicates different orientation in the Islamic development as well as the people's life when met with complex situation and culture. Afterward, the Islamic civilization development during Daulah Umayyah era in Damascus (661-750) and Daulah Umayyah era in Andalusia (750-1031)was based on the people's complexity that spreaded, whether in the growth of different religion communities or Muslim communities in ethnically-diversed areas. During the Umayyah Damascus caliphate era, even though Arabism political view was developed, it did not necessarily generate a mono-cultural society. Instead, the Arabic Muslim community at that time was based on local ethnicity, so that Muslim civilization could develop in a multicultural pattern in the scope of Arabic political hegemony. Arabic politic domination in the development of Islamic civilization in this era was limited mostly in interaction between Arabic-Muslim and the culture of nonArabic people, which caused multiculturalism that tended to be endogenous. In this period, multiculturalism grew in the Muslim community itself, either from the diversity in religion denominations or Arabic ethnicity basis. 
Different case occured to the multiculturalism development in Muslim civilization during Daulah Abbasiyah (750-1250) era. His caliphate showed the growth of exogenous multiculturalism communities. Multiculturalism started to surpass the internal Arabic-Muslim boundary as a result of interaction with non-Arabic and non-Islamic cultures. At this time, Islamic civilization had to struggle between Arabic and Persian, Roman, or Indian cultures. Universality in Islamic civilization was triggered by the caliphs' desire to introduce the non-Arabic culture to the Muslim civilization through translation and development of knowledge from those massive civilizations. Multiculturalism tendency also started from them being open to be influenced by non-Arabic culture and also the participation of nonArabic people during the process of shaping and improving Islamic civilization.

Therefore, this study attempts to dig deeper about the multiculturalism that grew and developed in Islamic civilization during the classic period. The analysis is guided by following questions: How was the formation and development pattern of Islamic communities? How was the multicultural life in every period of Islamic civilization? And why did multicultural communities occur among Islamic civilization?

This study is developed based on historical perspective, which examines all problems or issues and talks about the facts of all events in the classic period of Islam. This research emphasizes on socio-cultural phenomenons, so sociology and culture perspectives are used in this case. Based on the historical perspective, all social and cultural facts are viewed in their development process from one period to another. Based on the social approach, community concept is the main reference, while cultural perspective is developed especially 
based on the concept of multiculturalism. In turn, both concepts become the references in analyzing multiculturalism in Muslim civilization system.

\section{B. Discussion}

\section{Multicultural Communities in the Beginning of Islam}

It is an open secret that Arabic people in Mecca before Islam were living in tribes (qabilab). ${ }^{2}$ Furthermore, these Arabic qabilah communities can be explained using the life of major Quraisy qabilah in Mecca right before Islam was born. At that time, this qabilab consisted of 12 al-fakhiz or bani-the last one was Bani Abdul Manaf ibn Qushay ibn Kilab ibn Murrah ibn Kaab ibn Luay ibn Ghalib ibn Fihr. Abdul Manaf had four children, they were al-Mutthalib, Naufal, Abd asySyams and Hasyim. Hasyim then had a son named Abdul Mutthalib, the grandfather of Prophet Muhammad saw. Abdul Mutthalib was known for his success in continuing Hasyim's role related to as-Siqayah (water-providing for the pilgrims) dan ar-Rifa dah (food-providing for the pilgrims). Due to his tenacity and also the help from his son, alHarits ibn Abdul Mutthalib, he succeeded to rediscover the Zamzam Well that was previously hidden by Jurhum qabilah and had been in search for a long time from one generation to another. Abdul Mutthalib also succeeded to overcome the security challenge after the attack by Habsyi army-under the

\footnotetext{
${ }^{2}$ The system of Arabic communities before Islam had the qabilah's complexity categorization. Communities higher tha qabilah were called asy-sya'b (plural: asy-syu'üb), which is the furthest descendants, such as Sya'b Qahthan and Sya'b Adnan. Below it was al-qabilah (plural: al-qabái il). The third was al-imärah, such as Imärah Kinanah and Imäah Quraisy. The next was al-batn, such as Bani Abdul Manaf and Bani Makhzum. Fifth was al-fakb;z, such as Bani Hasyim and Bani Umayyah, and the last one was al-fas ilah, such as Bani Abi Thalib and Bani Abbas. Read, Abdul Aziz, Chiefdom Medina: Salah Paham Negara Islam (Jakarta: Pustaka Alvabeta, 2011), p. 197.
} 
command of Abrahah-that he was granted huge recognitions from Arabic qabilah. The qabilah was also often involved in a civil war known as Fijar War (Ayjam al-Fijr) that happened 25 years before the era of Prophet Muhammad saw. The war ended with an agreement called Hilf al-Fudul (Special Alliance) $)^{3}$ to help each other.

Social life in Arabic communities in Mecca shows correlation between economic elements and religion or politics. Trading had led some Quraisy leaders to wealth, while other leaders lived with lower financial status than them (had just adequate amount of money to live). They did the trading in Mecca-especially during the Hajj seasonand also to other countries like Yemen and Ethiopia during the winter, and Syria and Iraq during the summer. This tradition-in a long term-had weakened the battling skill of Quraisy qabilah, especially the Battah group (group of rich and wealthy people), so that they extremely depended on the Zawabir group (the poor people, including slaves) to secure their family and also Mecca. This social system is also parallel to government organization, even though it only applied among the rich Battah Quraisy, fighting each other for the throne. Another outcome from the Quraisy internal rivalry is that the Mecca citizens were used to territorial segregation based on social status. Social stratification based on financial status generated five categories of people, from the highest to the lowest are: the respected wealthy people (Ma'ala), reputable people with lower income (Sa'adab), Arabic and non-Arabic people (Mawīiti), the poor people excluded from their qabilah (Sya'alik), and slaves (Ariqqa). ${ }^{4}$

Arabic people in the period before Islam came (Jahiliyyah period) are known to have various beliefs and

${ }^{3}$ Ibid., p. 205-208.

${ }^{4}$ Ibid., p. 209-210. 
religions. Some of them believed in Allah and His singleness. Some others believed in Allah, but also worshipped statues/ figures as a media to make them feel closer to Allah. And some others only worshipped the statues, believing that they were the Gods that provided the sustenance in life. Among the last category were Jews, Christians, and Majusis. Some other did not believe in anything, or believed that God's law only applies for the earthly life and that there is no life after death. There were also people who believed in spirits and sky objects. ${ }^{5}$

Internalisation of the faiths or cultural tradition occured through the qabilah system. The qabilah's and cultural tradition's existence-agreed by the communities-were maintained fanatically ('asabiyyah). Through qabilah, they grew and became the comunity's pride. Even though fanaticism arised from the qabilab system, for the Arabs, 'asabiyyah is the aspect that enabled inter-qabilah balance or stability and ensured the member's individual rights and dignity. ${ }^{6}$

The qabilah potential as explained above made Prophet Muhammad saw. utilize it as a teaching/propaganda media. The spreading of Islam that was initially done secretly, began to be done towards close families and friends. ${ }^{7}$ His first followers were his wife Khadijah, his nephew that he had been taking care of, Ali ibn Abi Thalib, and his former slave, Zaid ibn Haritsah, who still lived in his house. That being said, Muhammad's first mission was in his own family. On the next mission, he was assisted by his friend, Abu Bakar, who brought along Usman ibn Affan, Zubair ibn Awwam, Abdurrahman ibn A'uf, Sa'ad ibn Abi Waqqash, dan Thalhah

${ }^{5}$ Ibid., p. 165.

${ }^{6}$ Ibid., p. 173.

${ }^{7}$ Badri Yatim, Sejarah Peradaban Islam Dirasah Islamiyah II (Jakarta: Raja Grafindo Persada, 1997), p. 16. 
ibn Ubaidillah and converted them to Islam in front of him. ${ }^{8}$ The next step was open propaganda, by calling out to public. The Prophet began to spread Islam and its influence to all people, both the rich people and slaves. It started in Mecca, and spreaded to other places. With his persistence, more and more people converted to Islam. It marked the origin of first small community of Islam followers in Mecca.

Prophet Muhammad's propaganda at the beginning received a very positive feedback from lower class people, which were slaves, for they highly demanded liberation and freedom. Otherwise, he received less feedback from the higher class community, which only came from his wife, families, and close colleagues. When he started his public propaganda three years after his prophecy, only few Quraisy leaders were willing to accept it. They even began to prevent him from spreading Islam. The more followers Muhammad had, the harder resistance the Quraisy gave him. However, Prophet Muhammad's safety and first missions were very supported by al-'asabiyyah al-qabaliyyah tradition, which involved Bani Hasyim and Bani al-Muthalib families to guarantee his security. ${ }^{9}$

Nevertheless, the Quraisy kept challenging him to prevent his propaganda and teachings. They assumed that the Prophet's strength was sourced from the well-respected Abu Thalib's protection, so they designed an unsuccessful plan to detach them from each other. Next attempt was by sending Walid ibn Mughirah together with Umarah ibn Walid-a strong and handsome man-to be exchanged with Prophet Muhammad. This suggestion was later vehemently rejected by Abu Thalib. After that, the Quraisy sent out Utbah ibn Rabah-an expert in rhetorics-to persuade Muhammad in

\footnotetext{
${ }^{8}$ Ibid., p. 19.

${ }^{9}$ Abdul Aziz, Chiefdom Medina, p. 214.
} 
stopping his teachings for wealth, power, and women, and just like the old times, the plan did not work out. ${ }^{10}$ Leaving the unsuccessful diplomatic attempts, the Quraisy started to fight violently. The leaders required all family to torture their Islam family members, to reconvert them from Islam. The cruelty of the Meccas towards Islam followers forced Prophet Muhammad to evacuate his friends away from the city.

History says that most of the Muslims who migrated (bijrab) to Habsyi (Ethiopia) for the first time were lower-class people. The next phenomenal hijrah of Prophet Muhammad and his friends was to Yatsrib in $622 \mathrm{M}$. This hijrah was not only for providing security for Muslims in Mecca, but also for uniting the Quraisy elements and the well-known power in Arab that were always against each other, al-Aus and al-Khazraj. ${ }^{11}$ As soon as the Prophet got into Yatsrib, the people welcomed him cheerfully. Since then, to honor him, Yathrib changed its name to Madinah an-Nabii (the Prophet's city), because that was where the light of Islam shone from. ${ }^{12}$ As time goes by, the city is now known simply as Medina.

After renaming Yathrib as Medina, the Prophet started mapping and censussing the people. He found out that Medina was a multicultural city. The heterogenity can be seen from the census result that showed only minority (1.500 people/15\%) of total 10.000 citizens were Muslim; while most of them were Arabic idolatrous or musyrik (4.500 people/45\%) and Jews (4.000 people/40\%). ${ }^{13}$ This heterogeneity became even clearer when each group was divided into many qabilahs or sub-groups. The Muslim can be

\footnotetext{
${ }^{10}$ Badri Yatim, Sejarah Peradaban Islam, p. 21.

${ }^{11}$ Abdul Aziz, Chiefdom Medina, p. 215.

${ }^{12}$ Badri Yatim, Sejarah Peradaban Islam, p. 22-24.

${ }^{13}$ Sami ibn Abdullah al-Maghluts, Atlas Perjalanan Hidup Nabi Mubammad (Jakarta: al-Mahira, 2008), p. 95.
} 
divided into big groups of Muhajirin (migrants) dan Anshar (non-migrants), which again divided into many qabilahs with contrasting traditions. Even so, the life in Medina remained peaceful that it became a modern/advanced city at that time. During his first year in Medina, Muhammad's first move was to decrease 'asabiyyah qabaliyyah spirit by establishing brotherhood/sisterhood relation (mu'akhkhah) between the Quraisy-based Muhajirins and the al-Khazraj or al-Aus-based Anshars. Prophet Muhammad built ukhuwwah Istamiyyah, which means a new brotherhood based on religion, instead of just blood relation. ${ }^{14}$

Prophet Muhammad's success in creating peace among the multicultural people in Medina was due to the close friendship he made with the non-Muslims. He conducted an agreement called the Charter of Medina, which protect the Jews right to keep their belief. Every group had their own specific rights and roles in politics and religions. Their religious freedom was guaranteed, and everyone had the duty of protecting the city from attacks. The charter stated that Prophet Muhammad was the head of government and given an absolute authority. In social aspects, he also set a foundation of fairness and equality. ${ }^{15}$ Hence, The Charter of Medina became a symbol of Islamic spirit in upholding democracy, equality, anti-racism, and justice between ethnics, race, or religions. Referring to the charter, Prophet Muhammad consolidated and united the people in Medina to prevent pressures from Mecca.

Under Muhammad's leadership-both in military and diplomacy-for ten years (622-632 M) in Medina, Islam continued to show its crystallization as a faith and sociopolitical system. From then, Muslim community has spreaded

\footnotetext{
${ }^{14}$ Abdul Aziz, Chiefdom Medina, p. 215.

${ }^{15}$ Badri Yatim, Sejarah Peradaban Islam, p. 26.
} 
and formed its hegemony in the Middle Arabian. Mecca was finally overpowered and the Arabic tribes were united in an Arabic commonwealth with similar ideology submitted to the law of central government. Muhammad's leadership accomplishments in uniting political powers indicate his loyalty to Arabic tribe system and its cultural values that were reformed by converting them to Islam. ${ }^{16}$ Since then, the unity of Arabic tribes that occurred in Medina has changed the social and political life in the Middle East, and turned into the biggest socio-political challenge for the surrounding area, including Persian and Roman empire.

Following the death of Muhammad, his successor in the leadership became controversy. It was because the Prophet did not leave any testament of who should step up as political and governmental leader for Muslims. This matter was left for discussion between Islam followers. The divided Islam followers (Anshars and Muhajirins) confused the decision of who the next caliph was even more. The period after the passing of Muhammad is known as al-Khulafa arRasyidun period.

Al-Khulafa ar-Rasyidun period is an important part of Islamic history. They were able to save, consolidate, and set the foundation for the glory of Islam. For about 30 years, this era was not only important, but also really special for their method in leadership immitated the Prophet's examples in accordance with the guidance from Allah swt. If Muhammad's era was considered as the time for sowing values of Islamic culture in Arabic cultural system, then-with the spread of Islam in different cultural systems-the teaching of Islam during the era of al-Khulafa ar-Rasyidun was done more smoothly.

${ }^{16}$ John L. Esposito, Islam dan Politik, transl. M. Joesoef Sou'yb (Jakarta: Bulan Bintang, 1990), p. 8. 
At this time, the Arabic-Muslim communities had spreaded into most of the Middle East. New Islamic civilizations were born not only at the border of Arab, but also in the center of Middle East civilization. The growth of those new civilizations went along with the takeover of Sasanian Empire and the eastern part of Byzantium Empire. Simultaneously, also happened a huge conversion from Jews, Christians, and Zoroastrians to Islam. Arab's occupation also encouraged a progressive social and cultural change among the Arabs and non-Arabs into several cosmopolitan communities. The formation of those new communities with their various cultural patterns can be observed more clearly during Khulafa al-Rasyidin's leadership, including: Abu Bakar ash-Shiddiq (11-13 H/632-634 M), Umar ibn al-Khaththab (13-23H/634-644 M), Utsman ibn Affan (23-35 H/644-656 $\mathrm{M})$, and Ali ibn Abi Thalib (35-40 H/656-661 M).

Multiculturalism in al-Khulafa ar-Rasyidun era that was supported by diverse social structure triggered social changes to happen in the area where Islam was spreaded. Begun with the development of new cities, the opportunities of economic for people changed; non-Arabic people tended to enter the Arabic-Muslim military, while the Arabs became landlords, traders, and permanent residents. Social transformations also occurred in the growth of mixed communities between Arabs and non-Arabs, and even the religious associations like charismatic preachers, Qur'an experts, theologians, Sufis, and others demanded new patterns for social organization.

\section{Multiculturalism During the Daulah Umayyah Period}

As the first dynasty in Islam, Daulah Umayyah held an important role in setting foundations for the glory of Islam, including the context in building its civilization. Studying deeper about the civilization in this era from multiculturalism 
perspective will impress a contrary with the history of Islam. It is due to the common sense that Daulah Umayyahespecially the one centered in Damascus-is famous for its Arabization policy. In fact, this administrative polical policy did not necessarily abolish the co-existence and significance of non-Arabic communities' role in the context of Islamic civilization development during Daulah Umayyah era in the East or West. As explained by Gerald Hawting, arabization is no more than a cultural construction and expansion marked by the application of Arabic language in every area under Islam's occupation (Daulah Umayyah) at that time. But in some part of the country, Jews and Christians remained important parts of Damascus and maintained their religious traditions, despite the change of language. ${ }^{17}$ In the meantime, the reaction towards arabization was different in Persia. There, Jews and Christians maintained their pre-Islamic language, either in everyday conversations or literatures. The use of language in Persia also went through plenty of significant changes at the beginning of Islamic period. ${ }^{18}$

Likewise, as the Umayyah expansion expanded, the adoption of Arabic culture was done optimally by Syria, Iraq, and Egypt. And although the people of Berber and Persia had converted to Islam and used Arabic as their religion's sacred language, both nations still maintained their original language for everyday communication. It can be assumed that arabization and Islamization were the mainstream cultural process during Daulah Umayyah occupation. ${ }^{19}$ However, social and cultural heterogenity was also made true during this era. The Arabic-Muslim nations started to make cultural contact with various older civilizations in the world, such as

${ }^{17}$ Gerald R. Hawting, The First Dynasty of Islam: the Umayyad Caliphate AD 661 750 (Southern Illinois: Southern Illinois University Press, 1987), p. 8.

${ }^{18}$ Ibid., p. 9.

${ }^{19}$ Ibid. 
Persian, Egyptian, or even Iberian peninsula in Europe. This condition urged the exchange and influence of one culture entity with another. The role of Daulah Umayyah caliphs also encouraged this acculturation. The most standing-out cultural aspects to represent creative forms as the result of the exchange were knowledge and architectural or applied construction aspect.

Other indication of multiculturalism during this period can be seen in Damascus people's structure that consisted of four main components; the Arabic Muslims, the non-Arabic Muslims, the non-Muslims, and slaves. The Arabic Muslims had the highest position in Damascus' social stratification. They were the ruler of Daulah Umayyah, both in the empire or Arabic aristocats associations. But this does not mean that the Arabic Muslims were majority in Damascus. ${ }^{20}$ As the capital of East Daulah Umayyah, Damascus had transformed into a city with Islam characteristics, despite the fact that the people (including the ones living in the small country parts, villages, or mountains) were generally Christians in the past. Those who kept preserving their Christianity maintained their cultural and religious identity during the Daulah Umayyah leadership. In the southern part of Damascus, especially in Lebanon, people maintained to be Christian and used Syrian language for their daily cconversations for centuries since Daulah Umayyah government. In the notes of Philip $\mathrm{K}$. Hitti, there was never a physical conflict in Damascus. Instead, competition in religion, race, social, and language constructed the social dynamics in Damascus. ${ }^{21}$

High diversity also applied for the composition of population in Andalusia during the Daulah Umayyah era.

${ }^{20}$ Philip K. Hitti, The History of the Arabs, tansl. R. Cecep Lukman Hakim and Dedi Slamet Riyadi (Bandung: Serambi, 2008), p. 74.

${ }^{21}$ Ibid., p. 75. 
The main population of Andalusia was Arabic Muslim communities and the Berbers. Both were important actors in liberation of Andalusia to be the center of power for Daulah Umayyah in the west. Other group was the Christian community as the native inhabitants in Andalusia. Some members of this community converted to Islam after their liberation from West Gothia's oppression. Arabic Muslim communities that settled in Andalusia after the liberation came from the south of Arab (Yemeni Tribes) and the north of Arab (Mudhari Tribes). Most of the Mudhari Tribes inhabited Toledo, Zaragoza, Sevilla, Valencia, etc.; while the Yemeni Tribes inhabited Granada, Cordoba, Sevilla, Murcia, and Badajoz. ${ }^{22}$ Other groups were Christians and Jews. Christians community in Andalusia can be identified as two general groups based on their cultural characteristics: (a) Christian communities who still preserved their old belief and tradition; and (b) Christian communities who still preserved their belief, but imitated the Arabic cultures-especially the Arabic language-in daily conversations, writings, or other aspects. This group is known as Musta'ribah. All communities-including Arabic Muslims, Christians, and Jews-held important roles in cultural development in Cordoba. The Christian communities were still free to use their churches and their religious leaders were still allowed to wear their religious uniforms. ${ }^{23}$ According to Kees De Jong, Jewish culture also intensely developed in Cordoba. One of the Jewish influential leaders during the Daulah Umayyah era was Hasday ibn Shaprut, the empire's doctor during Abdurrahman III and al-Hakam II government as well as a terrific intellectual. He once led the translation project of a Greek manuscript to Arabic. In fact, he was the one

${ }^{22}$ Ira M. Lapidus, Sejarah Sosial Ummat Islam II, transl. Ghufran A. Mas'udi (Jakarta: Raja Grafindo Persada,1999), p. 581.

${ }^{23}$ Ibid., p. 584. 
who started searching for the manuscript to the Byzantine kingdom. After being translated, the manuscript turned out to be extremely substantial for the people in Cordoba. ${ }^{24}$

It is stated in the history that there were no interreligion conflicts among social life in Damascus. Social conflicts was only experienced by some tribes, two of them were Himyariyah and Mudariyah. This inter-religious harmony was driven by government policies of the Daulah Umayyah that provide fair attention to other religions. The caliphs proportionally provided protection for the holy places for all religions in Damascus, such as churches, cathedrals, synagogues, and other holy sites. The Daulah Umayyah authorities had even adopted a policy to re-build Edessa's Christian churches after it was damaged by an earthquake. Cost of the rehabilitation was taken from the funds raised by Muslims. ${ }^{25}$

Daulah Umayyah government in Andalusia also issued policies that encouraged the process of imitation and acculturation among social entities there. Daulah Umayyah was known for its policies that respected the non-Islamic faiths-particularly Christian and Jews-and Arabic Muslims can interact freely and equally in the social rules that applied. Especially to the Christian and Jewish communities, Daulah Umayyah government even put both of them into the post of civilian and military authorities. To the Christian communities, Daulah Umayyah government chose a community leader (Count) from members of their own community. The Christian community also had representatives to convey their aspirations in the Daulah Umayyah caliphate. Daulah

${ }^{24}$ Kees De Jong, "Al-Andalus di Bawah Kekuasaan Daulah Umayyah di Cordoba (756-1031): Suatu Masyarakat Pluralistik yang Beradab”, Gema Teologia, Jurnal Fakultas Theologia Universitas Kristen Duta Wacana, Vol. 34, No. 1, April 2010, p. 19.

${ }^{25}$ Ibid., p. 21. 
Umayyah also appointed a particular person as a tax collector for this Christian community. ${ }^{26}$ The Jewish community had its own administrative autonomy as well; they even had their own autonomous region, located about 40 miles from the city of Cordoba. Another thing to pay attention to is the figure of Ibn Syibruth from the Jewish community who was given the authority to welcome ambassadors of various countries who came to Cordoba. He was also commissioned by the Daulah Umayyah to carry out diplomatic mission to the King of Navarre. Other communities were the Slavs brought by Abdurrahman an-Nashir to offset the tendency of Arabism in Andalusia. They were recruited to be educated in the military and became the caliph's bodyguards. The policy of Umayyah's caliphs as it was also their strong commitment to develop a culture and civilization in Andalusia, both physicalmaterial as well as mental-spiritual, that was being open to each community to participate actively in the construction of culture and civilization in Andalusia. ${ }^{27}$

Thus, Daulah Umayyah was able to bring the city of Cordoba to be one of the Islamic cultural centers at that time, in addition to Baghdad and Constantinople. This was driven by the principle of the Daulah Umayyah's policies related to the pattern of cultural development that emphasized egalitarianism, inclusiveness, and multiculturalism among various communities in Andalusia. Such policies were also able to reduce the turmoil uprising from the Christians. In contrast to the early attitude of the Christians, Jews actually responded positively since the beginning of the Muslims' arrival in the Iberian peninsula. As we know, since the 6th century $\mathrm{AD}$, Jews in Andalusia were discriminated by the

${ }^{26}$ Ibid., p. 50.

${ }^{27}$ James C. Conroy, "Do the Andalusian Caliphates Offer a Good Model for Intercultural Citizenship?", a paper in Inaugural Conference of the Jubilee Centre for Character and Values at Birmingham University, 2012, p. 6. 
oppressive policies of the Christian King of the West Gothia. Thus, the Muslims' arrival was regarded by the Jews as a new chapter of a better life. ${ }^{28}$ Another well-grounded policy underlying the attention of Daulah Umayyah in Andalusiaespecially during Abdurrahman III Caliphate-regarding inclusiveness, multiculturalism, and the co-existence situation was his initiative to recruit government officials from each community in Andalusia. This policy appeared to have put aside theological factor in governance. Administration officials were selected on the basis of their contribution to the country and not their positions in their respective communities, or their mastery in scriptures-for example-as a theological-religious reason. ${ }^{29}$

\section{Multicultural Communities During the Abbasiyah Period}

The situation of Iraq in general and Baghdad-before occupied by Bani Abbasiyah-particularly had had an old and long-established tradition. At least two major pre-Islamic traditions were there; Eastern Roman's (Bezantium) tradition and Persian tradition that had grown and was deeply rooted in people's lives in Iraq. Pre-Islamic culture in the territories covered various fields such as family structures and ideology of patriarchy, the social orders in agriculture, immigrants, market economy, and teachings of monotheism ${ }^{30}$. On the former territory of the Eastern Roman empires, also grew an Orthodox Christian tradition; other areas such as Abyssinia and Gassania were Monophite Christian; while in other regions such as Syria and Iraq, Nestorian Christian grew. This fact illustrates that the Abbasiyah Dynasty of Islam

${ }^{28}$ Ibid., p. 9.

${ }^{29}$ De Jong, "Al-Andalus di Bawah Kekuasaan Daulah Umayyah di Cordoba (756-1031): Suatu Masyarakat Pluralistik yang Beradab”, p. 66-67.

${ }^{30}$ Lapidus, Sejarah Sosial Ummat Islam II, p. 4. 
was faced with the diverse religions, ideologies, cultures, and social hierarchy tradition in the society.

Religious life in the Abbasiyah Dynasty territory was also supported by various local and immigrants religious groups. Religion that was considered as the "new comer" into Persian territory was Buddhism. Even in its development, Bani Abbasiyah family built a very intensive bond with one of the Buddha families named Barmaki. ${ }^{31}$ The family eventually converted to Islam and won the trust in Bani Abbasiyah government as the governor and finance minister. Even the educational process for the caliph Harun al-Rasyid was entrusted to this former Buddhist monks family. Although in the end-because of political considerations-the monk family was destroyed by one of the caliphs of the Bani Abbasiyah. ${ }^{32}$

To this reality of heterogeneous society, Ignasz Goldziher depicted two factors that made Arabic and nonArabic traditions complement each other to generate a new formula. In this case, the western orientalist wrote that the cultural dynamics were as follows: two kinds of influences determine the history of an institution. One of them is internal, whose impulses came from the institution and driving force moving it along its historic journey. Another is the intellectual influences from outside, which enrich the original core ideas, and thus has spawned its historical development. Impulses of the first category is not lacking in Islam. However, the most important stages in its history was marked by assimilation with foreign influences. Dogmatic development of Islam took place according to the Greek point of view; in its legal system, the influence of Roman law cannot be doubted; nation organizations like the one formed

\footnotetext{
${ }^{31}$ Hitti, The History of the Arabs, p. 365-368.

${ }^{32} \mathrm{M}$. Abdul Karim, Sejarah Pemikiran dan Peradaban Islam (Yogyakarta: Bagaskara, 2012), p. 150.
} 
during the Abbasiyah caliphate showed the adaptation of Persian political ideas; while Islamic tasawuf/mysticism used Neoplatonism and Hinduism's way of thinking. ${ }^{33}$

The most prominent economy sectors during Bani Abbasiyah era were trade and industry. In the beginning, the pace of trade at that time was controlled by Christians, Jews, and Zoroastrians. But in the end, the pace was affected by Arabic Muslims, making the ports like Baghdad, Basra, Siraf, Cairo, and Alexandria as centers of trade. Trade areas explored by the Muslim merchants include China, Morocco, and Spain. Among the trading objects were dates, sugar, cotton, wool fabrics, and tools of steel and glass. From Asia, they took ivory and ebony, while from Africa they took home the black slaves. ${ }^{34}$

Portrait of the trade traffic in Abbasiyah period became the evidence that caliphate in Baghdad built relationships with various groups of people with different ideological and cultural backgrounds with similar success goal in trading. This reality allowed a multicultural ethics that can be agreed by all people. Values of Islam were perhaps not the only one taken into consideration in building a multicultural ethics among the traders. But by holding on to the basis of religious background that had developed in Persia for a long time, it can be assumed that the ethics they promoted were built on various religious values developed there, such as Jewish, Christian, Buddhist, ancient Persia religion, and ethical values of Islam itself.

Although Bani Abbasiyah ruled using Islamic laws, but they still provided freedom for local people who still upheld their old culture and local values. These upholders came

${ }^{33}$ Ignaz Goldziher, Pengantar Teologi dan Hukum Islam, transl. Heri Setiawan (Jakarta: INIS, 1991), p. 2.

${ }^{34}$ Hitti, The History of the Arabs, p. 428-430. 
from citizens called zimmi. According to Hitti, in both cities and villages, the zimmi clinged to their culture and maintained their native language, such as Aramaic culture and language, Syrian in Syria and Iraq, Iranian culture and language in Persia, or Coptic culture and language in Egypt. Most of them then converted to Islam and moved to the cities. ${ }^{35}$

Meanwhile, another portrait of local culture preservation is seen in the use of language in the communities. The use of Arabic language in the communities had been running massively and evenly at the end of Abbasiyah Dynasty. Eventhough Arabic at that time was used as academic and casual language of the people, but it never managed to replace the Iranian language, which had long been established as the language of conversations. This phenomenon also occured among Christian Lebanons that maintained the native Syrian language and strongly rejected the influence of Arabic. ${ }^{36}$ This fact shows that the influence of Arabic culture-especially the language-was not able to influence the local culture, and local culture was free to develop.

In addition to the fact that Arabic language could not replace local language, at the same time, Abbasiyah Dynasty adopted the concept, tradition, and political culture of the Persian. This asserts that universal Islamic values remained capable to collaborate with the local cultures. Adoption of the local culture-especially the legacy of Sasanian kingsbecame an integral part in the life of the Abbasiyah Dynasty. Goldziher wrote as follows: “despite of the Abbasiyah's growing obsession for the grandeur and greatness of Sasanian kings, the words of piety were everyday consumption. The

\footnotetext{
${ }^{35}$ Ibid., p. 441.

${ }^{36}$ Ibid., p. 452.
} 
idea of Persian government that brought together religion and nation was clearly the Abbasiyah's plan." ${ }^{37}$

\section{Conclusion}

Multiculturalism in Islamic classic period showed its diverse patterns in the development of three Muslim communities.

Firstly, in the early period of Islam (the period of Prophet Muhammad and al-Khulafa ar-Rasyidun), Muslim communities were still based on Arabic cultures. This period includes Muslim communities that were rooted in al-'asabiyyah al-qabaliyyah tradition. This tradition was critical in pioneering the establishment of the Muslim community system, both for the development of social structure and civilization. Arab's socio-cultural potential did not only become the objective target in uniting Muslim community's identity, but it was also accommodated in the process of their lives, as reflected in the Medina community and its influence in areas of Islamic occupancy.

Secondly, Daulah Umayyah-especially the ones centered in Damascus-was famous for their Arabization policy. This policy-which emphasized on mono-culturalism-was the antithesis of multiculturalism. However, the political administrative policy did not necessarily negated the coexistence and significance of the role of non-Arabic communities in Islamic culture and civilization context during Daulah Umayyah reign, both in the East and West.

Thirdly, during the reign of Abbasiyah, despite the process of awakening Muslim communities on the importance of Islamic law, local people were still given the freedom to uphold their culture and local values. These

\footnotetext{
${ }^{37}$ Goldziher, Pengantar Teologi dan Hukum Islam, p. 44.
} 
upholders came from citizens called zimmi. This caused the existence of Bani Abbasiyah in Persia only served as filters and progressors of Persian civilization history. But still, during its governance, Bani Abbasiyah also generated new civilization in science, ethic development, governance models, as well as art and literature, which were all built on the basis of multiculturalism. 


\section{REFERENCES}

Abdullah, M. Amin., et al. Tafsir Baru Studi Islam dalam Era Multi Kultural. Yogyakarta: IAIN Sunan KalijagaKurnia Kalam Semesta, 2002.

Abdurahman, Dudung. Metodologi Penelitian Sejarah Islam. Yogyakarta: Ombak, 2011.

Aziz, Abdul. Chiefdom Medina: Salah Paham Negara Islam. Jakarta: Pustaka Alvabeta, 2011.

Burke, Peter. Sejarah dan Teori Sosial, transl. Mestika Zed and Zulfami. Jakarta: Yayasan Obor Indonesia, 2001.

Coope, Jessica A. "Religious and Cultural Conversion to Islam in Ninth-Century Umayyad Cordoba", Journal of World History, University of Hawaii Press, Vol. 4, No. 1, 1993.

De Jong, Kees. "Al-Andalus di Bawah Kekuasaan Daulah Umayyah di Cordoba (756-1031): Suatu Masyarakat Pluralistik yang Beradab", Gema Teologia, Jurnal Fakultas Theologia Universitas Kristen Duta Wacana, Vol. 34, No. 1, April 2010.

Esposito, John L. Islam dan Politik, transl. M. Joesoef Sou'yb. Jakarta: Bulan Bintang, 1990.

Fauzi, Ihsan Ali. "Convivencia di Andalusia", Democracy Project, Yayasan Abad Demokrasi Jakarta, ed. 039, December 2011.

Goldziher, Ignaz. Pengantar Teologi dan Hukum Islam, transl. Heri Setiawan. Jakarta: INIS, 1991.

Hassan, Ibrahim. Sejarah dan Kebudayaan Islam, transl. Djahdan Humam. Yogyakarta: Kota Kembang, 1989. 
Hawting, G.R. The First Dynasty of Islam: the Umayyad Caliphate $A D$ 661-750. Southern Illinois: Southern Illinois University Press, 1987.

Hitti, Philip K. The History of the Arabs, transl. R. Cecep Lukman Hakim and Dedi Slamet Riyadi. Bandung: Serambi, 2008.

Iqbal, Muhammad. The Reconstruction of Religious Thought in Islam. Lahore: S.H. Muhammad Ashraf, 1971.

Issawi, Charles. Filsafat Islam Tentang Sejarah, transl. A. Mukti Ali. Jakarta: Tintamas, 1976.

James C. Conroy. "Do the Andalusian Caliphates Offer a Good Model for Intercultural Citizenship?”, paper in Inaugural Conference of the Jubilee Centre for Character and Values at Universitas Birmingham, 2012.

Karim, M. Abdul. Sejarah Pemikiran dan Peradaban Islam. Yogyakarta: Bagaskara, 2012.

Kartodirdjo, Sartono. Kebudayaan Pembangunan dalam Perspektif Sejarah. Yogyakarta: Gadjah Mada University Press, 1980.

- Pemikiran dan Perkembangan Hiostoriografi Indonesia Suatu Alternatif. Jakarta: Gramedia, 1982.

- Pendekatan Ilmu Sosial dalam Metodologi Sejarah. Jakarta: Gramedia, 1992.

Kuntowijoyo. Identitas Politik Umat Islam. Bandung: Mizan, 1997.

. Metodologi Sejarah. Yogyakarta: Tiara Wacana, 1994.

Lapidus, Ira M. Sejarah Sosial Ummat Islam II, transl. Ghufron A. Mas'udi. Jakarta: Rajawali Pers, 2000.

al-Maghluts, Sami ibn Abdullah. Atlas Perjalanan Hidup Nabi Muhammad. Jakarta: al-Mahira, 2008. 
Mahfud, Choirul. Pendidikan Multikultural. Yogyakarta: Pustaka Pelajar, 2001.

Pulungan, J. Sayuthi. Prinsip-prinsip Pemerintahan dalam Piagam Medina Ditinjau dari Pandangan al-Qur'an. Jakarta: Raja Grafindo Persada, 1996.

Sardar, Ziauddin. Rekayasa Masa Depan Peradaban Muslim, transl. Rahmani Astuti. Bandung: Mizan, 1986.

Shibel, Fuad Muhammad. Kebudayaan Islam Menurut Tinjauan Toynbee, transl. Bustani A. Gani and Chatibul Umam. Jakarta: Bulan Bintang, 1977.

Shihab, Alwi. Menuju Sikap Terbuka dalam Beragama. Bandung: Mizan, 1999.

Von Grunebaum, Gustave E. Modern: The Search for Cultural Identity. New York: Ancore, 1964.

Wahid, Abdurrahman. Pergulatan Negara, Agama, dan Kebudayaan. Depok: Desantara, 2001.

Watt, W. Montgomery. Kejayaan Islam: Kajian Kritis dari Tokoh Orientalis, transl. Hartono Hadikusumo. Yogyakarta: Tiara Wacana, 1990.

Yatim, Badri. Sejarah Peradaban Islam Dirasah Islamiyah II. Jakarta: Raja Grafindo Persada, 1997. 
Dudung Abdurahman

Halaman Ini Tidak Sengaja Untuk Dikosongkan. 